\title{
EVIDENCE OF THE RELATIONSHIP BETWEEN BUDGETARY PARTICIPATION, ORGANIZATIONAL COMMITMENT AND MANAGERIAL PERFORMANCE
}

\author{
EVIDÊNCIAS DA RELAÇÃO ENTRE PARTICIPAÇÃO \\ ORÇAMENTÁRIA, COMPROMETIMENTO \\ ORGANIZACIONAL E O DESEMPENHO GERENCIAL
}

Submission: 25/05/2019

Accept: 30/04/2020

\author{
Andréia Acássia Guidini ${ }^{1}$ \\ Vinícius Costa da Silva Zonatto 2 \\ Larissa Degenhart ${ }^{2}$ \\ 1 University of the Contestado (UnC), 2 Federal University of Santa Maria (UFSM)
}

\begin{abstract}
Purpose - This research objective to investigate the relations between budgetary participation, organizational commitment and managerial performance.

Design/methodology/approach - A descriptive, survey and quantitative study was carried out, based on trajectory analysis and with data from 150 managers with budgetary responsibilities of the largest Brazilian export companies in the business.

Findings - The results reveal that budgetary participation influences managerial performance in two ways: directly, as a result of managers 'involvement and influence in the budgeting process, and indirectly, when managers' commitment to the organization increases due to their participation and involvement in budgetary definitions.

Research limitations/implications - The limitation of the use of self-reported measures to measure the proposed relationships is highlighted. This research indicates that behavioral aspects related to the budgeting process, have significant implications for work-related results.

Practical implications - The results suggest that organizations should allow the participation of managers in setting goals and budget objectives, as this action triggers a greater commitment of the individual to the organization and better performance in the work.

Social implications - The findings can help organizations to understand factors that can be improved in the organization so that employees feel committed to the company in which they operate and consequently present better budgetary participation and performance.

Originality/value - This research sought to expand the existing discussion in the accounting literature on the role of budgetary processes and their implications for organizational commitment and managerial performance in budgetary activities.
\end{abstract}

Keywords: Budgetary Participation. Organizational Commitment. Managerial Performance. 


\section{RESUMO}

Objetivo - Esta pesquisa objetiva investigar as relações entre participação orçamentária, comprometimento organizacional e o desempenho gerencial.

Desenho/metodologia/abordagem - Realizou-se um estudo descritivo, de levantamento e quantitativo, a partir da análise de trajetórias e com os dados de 150 gestores com responsabilidades orçamentárias das maiores empresas brasileiras do ramo de exportação.

Resultados - Os resultados revelam que a participação orçamentária melhora o desempenho gerencial de duas maneiras: diretamente, como consequência do envolvimento e influência dos gestores no processo orçamentário e indiretamente, quando o compromisso dos gestores com a organização aumenta devido à sua participação e envolvimento nas definições orçamentárias.

Limitações/implicações da pesquisa - Destaca-se a limitação da utilização de medidas auto relatadas para a medição das relações propostas. Esta pesquisa indica que aspectos comportamentais relacionados ao processo orçamentário, apresentam implicações significativas para os resultados relacionados com o trabalho.

Implicações práticas - Os resultados sugerem que as organizações devem permitir a participação dos gestores no processo de definição de metas e objetivos orçamentários, visto que esta ação desencadeia um comprometimento maior do indivíduo com a organização e melhor desempenho no trabalho.

Implicações sociais - Os achados podem ajudar as organizações no entendimento de fatores que podem ser melhorados na organização para que os funcionários se sentem comprometidos com a empresa em que atuam e consequentemente apresentem melhor participação orçamentária e desempenho.

Originalidade/valor - Esta pesquisa buscou ampliar a discussão existente na literatura contábil sobre o papel dos processos orçamentários e suas implicações para o comprometimento organizacional e o desempenho gerencial em atividades orçamentárias.

Palavras-chave: Participação Orçamentária. Comprometimento Organizacional. Desempenho Gerencial.

\section{INTRODUCTION}

In the accounting and management control literature, considerable attention has been given to the behavioral effects of managers on budgetary participation (Rengel et al., 2020), as budgeting is considered one of the tools for assessing managers' performance (Hariyanti et al., 2015) and can contribute to performance improvement (Lidia, 2015). According to Covaleski et al. (2007), research developed and based on psychology focuses on the individual level of analysis, as the effects of the budget vary between individuals.

Research into budget participation has focused on how managers react to the opportunity to participate in the budget process, as this process may affect individuals' attitudes and behaviors (Macinati et al., 2016), as well as their commitment to the organization in which (Mowday et al., 1979). Thus, budget participation is an important planning and control process in which managers can establish their objectives and those of the organization, as a relevant variable to improve work outcomes and organizational commitment (Subramaniam et al., 2002).

However, the relationship between budgetary participation and managerial performance has been showing contradictory results, that is, positive (Noor \& Othman, 2012; Almasi et al., 2015), negative (Etemadi et al., 2009; Dakhli, 2010) and without significance (Chong et al., 2006; Venkatesh \& Blaskovich, 2012; Jermias \& Yigit, 2013). This finding suggests that other variables intervene in this relationship (Derfuss, 2016, Dani et al., 2017), such as organizational commitment, the focus of this study.

Organizational commitment is related to the identification and loyalty of the individual with the company in which he Works (Porter et al., 1974; Mowday et al., 1979; Ketchand \& Strawser, 2001). In this way, individuals committed to the organization identify with the success of the company (Parker \& Kyj, 2006). A configuration in the organizations that can trigger the organizational commitment of the individuals is the budget participation, as the budget is recognized as 
a managerial tool that aims at the communication between superiors and their subordinates and improves the working environment (Ronen \& Livingstone, 1975). According to Mowday et al. (1979), organizational commitment is considered an important variable for the understanding of individuals' behavior at work. Budgetary participation can improve individuals' commitment to the organization because participating in and influencing the budget process will trigger greater acceptance of the organization's goals and values, greater effort to achieve goals, and a greater desire to remain in the organization (Mowday et al., 1979).

Evidence found in the literature suggests that budgetary participation increases commitment to the organization (Nouri \& Parker, 1998; Subramaniam \& Mia, 2001; Subramaniam et al., 2002; Chong et al., 2006; Nor Yahya et al., 2008; Ni et al., 2009; Sugioko, 2010; Wong-On-Wing et al., 2010; Noor \& Othman, 2012; Almasi et al., 2015), and improves the individual's performance at work (Nouri \& Parker, 1998; Chong et al., 2006; Nor Yahya et al., 2008; Ni et al., 2009; Wong-On-Wing et al., 2010; Noor \& Othman, 2012; Hariyanti et al., 2015).

Such evidence is important because it provides a more complete understanding of the influence of budget participation on work-related managerial outcomes, which encourages the development of new research, as these relationships have not yet been investigated in the Brazilian scenario, which indicates a gap for the accomplishment of this study. Moreover, for the behavioral accounting literature, the motivational effects of budget participation need to be further investigated to contribute to the development of this area in accounting.

Nouri and Parker (1998) argue that organizational commitment involves the belief and acceptance of organizational goals and values, and participation in budgeting can increase levels of organizational commitment of individuals. According to Chong and Johnson (2007), when employees are committed to the organization, they tend to exert additional effort to achieve the budget objectives, which results in a better performance in budget activities. To this end, budgetary participation has a motivational effect on individuals, which makes them accept and commit to budget goals. Consequently, such conditions tend to increase the individual's performance at work (Chong et al., 2006; Chong \& Johnson, 2007).

The opportunity to take part and be involved in the definition of budgets makes the subordinates feel more involved in the budget process, perceive a greater sense of control and trust, which results in greater organizational commitment (Chong \& Johnson, 2007). Once the organization ensures that the subordinates receive support during the budget process and for the performance of their tasks the subordinate's connection with the organization will probably increase (Nouri \& Parker, 1998).

Given the context presented, the problem that guides the development of this study is: What are the relationships between budgetary participation, organizational commitment, and managerial performance? Thus, this research aims to investigate the relationships between budgetary participation, organizational commitment, and managerial performance.

This study is justified because the involvement of the employees' ego with their work-related goals can be transformed into a greater commitment to the organization, as the budget participation can generate the identification of the managers with the budgetary and organizational goals (Subramaniam et al., 2002). Moreover, although budgetary participation was one of the most researched areas in managerial and behavioral accounting, few individual variables related to budget participation and managerial performance were considered in the studies developed under this theme (Agbejule \& Saarikoski, 2006). This research is also justified because, according to Ortiz et al. (2018), job satisfaction and organizational commitment are probably the most studied attitudes of human behavior at work, given their critical implications on the effectiveness of organizations. 
This research contributes to budget management practices and their effects on the attitudes of managers with budgetary responsibilities who work in Brazilian organizations, as the budget participation reflects on the actions of individuals in the work environment. Also, it aims to contribute to professional controllers, as the results found can provide contributions to the understanding of the motivational effects of participation in the budget processes and can create opportunities in companies for the development of training and training of these professionals, with the aim of the managerial performance in budgetary activities. In general, the research contributes to the evaluation of the adoption of participatory budgeting, considering its potential impact on the commitment of managers to the organization, which, in turn, enhances their performance in the workplace.

\section{THEORETICAL FOUNDATION AND HYPOTHESES}

\subsection{Budgetary Participation and Managerial Performance}

One form of employee participation relevant to research in the accounting area is budgetary participation, as it may have positive effects on the performance of individuals at work (Parker \& Kyj, 2006; Hariyanti et al., 2015). According to Nor Yahya et al. (2008), there is a critical mass of research on the relationship between budgetary participation and managerial performance, as the results found in the literature are inconsistent (Chong \& Johnson, 2007; Derfuss, 2016; Dani et al., 2017).

In Otley's (1978) view, to evaluate the managerial performance of individuals, it is necessary to consider some measure, in which performance can be related, as it involves questions of effectiveness and efficiency. In this sense, the budget can play a relevant role in this process, since budget participation can represent standards of efficiency and effectiveness in managers (Otley, 1978). However, the results of Nouri and Parker (1998) suggest that the relationship between budgetary participation and work performance is complex. Budgetary participation refers to the involvement of managers and their influence in the definition of the budgets of the units that act (Shields \& Shields, 1998; Parker \& Kyj, 2006). On the other hand, the managerial performance is defined concerning the fulfillment of important managerial tasks (Mahoney et al., 1963, 1965), as the budgetary ones in this research.

Several studies have found a positive relationship between budgetary participation and employee performance at work (Nouri \& Parker, 1998; Mia \& Patiar, 2002; Lau \& Tan, 2005; Agbejule \& Saarikoski, 2006; Chong \& Johnson, 2007; Nor Yahya et al., 2008; Sugioko, 2010; Noor \& Othman, 2012; Almasi et al., 2015; Hariyanti et al., 2015). We also found evidence of a negative effect (Etemadi et al., 2009; Dakhli, 2010), and also, that the budgetary participation does not impact on the managerial performance (Chong et al., 2006; Venkatesh \& Blaskovich, 2012; Jermias \& Yigit, 2013; Lidia, 2015; Macinati et al., 2016). However, the study by Macinati et al. (2016) presented results that the effects of budget participation on managerial performance may not occur directly, but indirectly through psychological and behavioral variables of individuals.

These inconclusive results may exist for the lack of understanding of the mechanism by which budgetary participation may affect managerial performance in activities (Chong \& Johnson, 2007; Her et al., 2018), such as organizational commitment. Despite these findings, researchers in managerial accounting show that budgetary participation is considered a means to improve managerial results ( $\mathrm{Ni}$ et al., 2009). These conflicting results between budget participation and managerial performance stimulate the development of new research (Zonatto, 2014; Her et al., 2018).

There is evidence in the literature that the budget process enables subordinates to share information with their superiors, to coordinate their interdependencies, and to trigger attitudes and 
behaviors in the work environment (Shields \& Shields, 1998). Search results for Francis-Gladney et al. (2004) found that organizations that allow subordinates to participate in the budget process have better communication with their superiors, reflecting better explanations for budgetary and performance. In this sense, budgetary participation improves managerial performance (Almasi et al., 2015).

Another explanation for the positive relationship between budget participation and managerial performance is that the perceived relationship between managers and their superiors and the incentive to take part in budget processes affects the performance of managers at work (Mia \& Patiar, 2002). However, the participation or not of the development of the budget must be equivalent to the attitudes and motivations of the managers, so that the performance in the budget activities is favorable (Dani et al., 2017).

Given the aforementioned context, it is suggested that there is a positive relationship between budgetary participation and managerial performance in budget activities, according to the following research hypothesis: $\mathbf{H 1}$ : There is a positive relationship between budgetary participation and managerial performance.

According to Nouri and Parker (1998), the link between budgetary participation and performance at work may reflect a direct and indirect relationship through intervening variables that are omitted from the analysis models. Thus, the budgetary participation contributes to predicting the performance of individuals directly and indirectly when it increases the organizational commitment (Nouri \& Parker, 1998; Noor \& Othman, 2012). Thus, conflicting results from empirical research provide researchers with an opportunity to investigate intervening variables in the relationship between participation and performance (Macinati et al., 2016). Moreover, the psychological theory presupposes an indirect relation between budgetary participation and managerial performance, being mediated by other variables (Shields \& Shields, 1998; Covaleski et al., 2007; Derfuss, 2016).

\subsection{Budgetary Participation and Organizational Commitment}

In contemporary times, organizations face increasing competitive pressure, and to survive under these conditions and increase competitiveness, one of the management concepts developed is organizational commitment (Serna et al., 2018), which can be enhanced by through the effective participation of managers in the budget context. Also, organizations have shown significant changes in their behavior (Soares et al., 2011). Therefore, among the reasons for investigating the managers' commitment to the organization is the belief that a good attitude toward the company will present a more effective managerial performance for the organization (Milani, 1975). Milani (1975) analyzed the attitude towards the company, which presents reflexes for the organization, and in this study, the focus is centered on organizational commitment, which also shows organizational reflexes.

Thus, due to their potential to improve the results of budget activities, organizational commitment has been the focus of studies (Nouri \& Parker, 1998). Concerning budgetary participation and commitment to the organization, several researchers in management, accounting, and psychology have proposed that the involvement of employees in decision making increases their commitment to the organization they work in (Parker \& Kyj, 2006). Empirical studies have evidenced a positive relationship between budgetary participation and organizational commitment (Nouri \& Parker, 1998; Subramaniam \& Mia, 2001; Subramaniam et al., 2002; Chong et al., 2006; Nor Yahya et al., 2008; Ni et al., 2009; Sugioko, 2010; Wong-On-Wing et al., 2010; Noor \& Othman, 2012; Almasi et al., 2015). The results of the role of attitudes towards budget decision-makers are consistent with most of the studies developed from this theme (Ni et al., 2009). 
In the research by Nouri and Parker (1998), the authors explored the effects of budgetary participation on managerial performance, through two intervening variables: budget adequacy and organizational commitment, confirming a positive relationship between budget participation and commitment with the organization. To this end, the evidence suggests that budgetary participation can lead to high budget adequacy by managers, which can increase managerial performance directly and indirectly through organizational commitment (Nouri \& Parker, 1998). It is noted that from the participation of the managers in the budget processes; it becomes possible to increase the levels of commitment of these with the organization, which consequently presents positive effects in the performance of the budgetary activities (Nouri \& Parker, 1998; Chong et al., 2006; Wong-On-Wing et al., 2010).

Individuals' commitment to the organization may make them more qualified to receive extrinsic rewards, such as bonus and rewards, and intrinsic rewards such as job satisfaction and better relationships with their peers and superiors (Subramaniam \& Mia, 2001), which is provided to individuals through the participation of budgetary processes. In this way, the level of participation in these processes should affect their commitment to the organization (Subramaniam et al., 2002). The results of Subramaniam et al. (2002) support this statement, as they found a direct and positive relationship between such relationships. In this sense, managers are usually involved in the strategic decisions of organizations, including defining the budget goals, thus, a better understanding of the factors that generate the commitment to the organizational objectives, becomes increasingly relevant at the managerial level (Subramaniam et al., 2002).

From the results of a positive relationship between budgetary participation and managerial performance, $\mathrm{Ni}$ et al. (2009) suggest that greater organizational commitment correlates with greater acceptance and commitment to organizational goals and value. Participation in budget decision making has direct and indirect effects on organizational commitment, which improves managers' performance in the budget context (Ni et al., 2009; Sugioko, 2010). These results also show that participation in the budget processes contributes significantly to predicting the organizational commitment of the managers. Besides, managers involved in participatory budgeting will develop a greater commitment to the organization (Noor \& Othman, 2012; Almasi et al., 2015).

Regarding the impact of budget participation on the organizational commitment Almasi et al. (2015) present some recommendations for organizations to improve this relationship. The authors recommend presenting budget feedbacks, suggestions for the development, and definition of budgets, thus improving organizational confidence and showing positive impacts on the commitment of managers to the organization (Almasi et al., 2015).

Considering the results found in the empirical literature on the subject analyzed, it is proposed that the motivational function of budgetary participation increases the levels of organizational commitment of managers with budgetary responsibilities. To do so, this research suggests that budget participation is positively related to organizational commitment, as this commitment involves the belief and acceptance of organizational goals and values that can be enhanced through the participation of individuals in the budget processes (Nouri \& Parker, 1998). The above context suggests the hypothesis: H2: Budgetary participation is positively associated with organizational commitment.

\subsection{Organizational Commitment and Managerial Performance}

Employees highly committed to the organization present better job performance than those less committed, as committed employees are more willing to exert greater effort to develop their tasks and reach objectives (Mowday et al., 1974). Eliyana and Ma'arif (2019) also address that 
organizational commitment has a significant impact on work performance.

In the area of organizational behavior, studies conducted with a focus on the organizational commitment of employees have received special attention due to their role in promoting a broader understanding of the relationships established between managers and their organizations. It is suggested that organizational commitment impacts on the performance and behavior of individuals at work (Leite et al., 2014; Eliyana \& Ma'arif, 2019). Studies were carried out to test the variables that contribute to the development of this link and the expected consequences of a greater impairment, such as performance at work (Leite et al., 2014).

Studies have suggested that managers with higher levels of commitment to the organization perform better in budget activities (Nouri \& Parker, 1998), which reveals a positive and significant association between such relationships (Nouri \& Parker, 1998; Chong et al., 2006; Nor Yahya et al., 2008; Ni et al., 2009; Wong-On-Wing et al., 2010; Noor \& Othman, 2012). However, this relationship was not presented directly and significantly in the study of Parker and Kyj (2006), but indirectly, mediated by other intervening variables. The results found by Sugioko (2010), Almasi et al. (2015), and Eliyana and Ma'arif (2019) revealed that organizational commitment did not significantly improve the performance of individuals at work.

The findings of Parker and Kyj (2006) indicate that commitment to the organization would not be directly related to performance at work but rather indirectly influence performance through the sharing of information in the budget context. In other words, information sharing mediates the relationship between organizational commitment and performance in budget activities (Parker \& Kyj, 2006). However, other research has found a direct relationship between organizational commitment and managerial performance, which shows that managers are strongly committed to an organization, accept organizational goals, and strive harder to achieve objectives, which improves their performance in activities ( $\mathrm{Ni}$ et al., 2009). Budgetary participation triggers the effect of individuals committing themselves to the organization, which improves managerial performance ( $\mathrm{Ni}$ et al., 2009).

Based on this positive relationship between organizational commitment and work performance, Noor and Othman (2012) revealed that this association suggests that organizational commitment contributes significantly to the performance improvement of individuals at work. In this way, the more committed managers are to the organization, the more motivated and dedicated they will be with their work, resulting in better managerial performance (Noor \& Othman, 2012).

The research of Almasi et al. (2015) provides some recommendations for organizations to improve this relationship in the work environment, that is, to improve the criteria for planning, coordination, evaluation, recruitment, and organization of human resources, as well as negotiation and representation to improve confidence in managers. In this sense, the organizational commitment that encompasses the acceptance of organizational goals and the sense of commitment and attachment to the organization is facilitated by motivation (Gagné \& Deci, 2005), which can be encouraged in individuals through participation in budget processes.

The motivation to share information in the budget context may depend in part on organizational commitment, as individuals who are highly committed to the organization want it to succeed, which makes them reveal private information that can be used to improve the performance of subordinates and the organization (Parker \& Kyj, 2006). Therefore, it is suggested that: H3: Organizational commitment is positively associated with managerial performance. 


\section{SEARCH METHOD AND PROCEDURES}

Based on the objective of investigating the relationships between budgetary participation, organizational commitment, and managerial performance, descriptive research was developed, with an exploratory characteristic, carried out through a survey and with a quantitative approach of the data. For a better understanding of the relationships proposed in this research, in Figure 1, a synthesis is presented.

Figure 1 - Theoretical analysis model

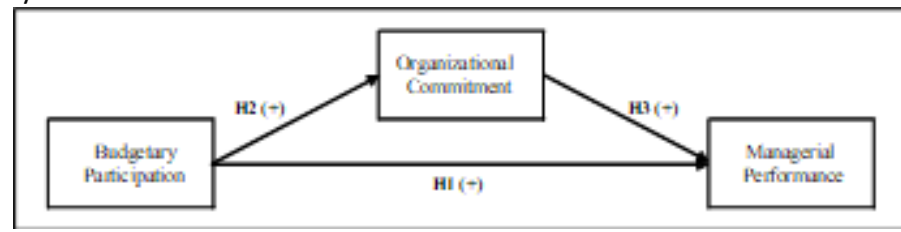

Source: Prepared by the authors.

Data was collected using an online survey questionnaire sent to managers with budgetary responsibilities of the largest Brazilian companies in the export sector, which had a participatory budgetary configuration. The companies that make up the study population were selected on the website of the Ministry of Development, Industry and Foreign Trade (http://www.desenvolvimento. gov.br), as this website lists the list of Brazilian companies with export operations in Brazil year 2014 (two thousand and fourteen). Subsequently, the exporting companies were ranked in descending order, considering the export value ranges to constitute the sample of the study, thus comprising 400 (four hundred) companies.

Of these 400 companies, 379 (three hundred and seventy-nine) managers were contacted, and of these 150 (one hundred and fifty) questionnaires were returned. Two managers per company participated in the survey, to reach a representative sample for the analysis of the proposed theme. The functional areas analyzed were industrial organizations in the segments of food, pharmaceutical, chemical, wood, furniture, steel, machining, casting, mining, weaving, technology, and vehicles. These sectors were chosen to comprehensively investigate budget participation in the Brazilian context. In these companies and sectors were analyzed the departments of budget, controlling, accounting, administration, commercial, financial, and/or production.

In this research, the following constructs were used: budget participation, organizational commitment and managerial performance. To measure budgetary participation, the questionnaire of six indicators of Milani (1975) was used. This instrument aims to assess the involvement and influence of the respondent in the budget process through a scale ranging from [1] totally disagree to [7] strongly agree. In management research carried out in the accounting area, this instrument was used by several authors (Nouri \& Parker, 1998; Chong et al., 2006; Parker \& Kyj, 2006; Wong-OnWing et al., 2010; Zonatto, 2014).

The instrument of nine indicators by Mowday et al. (1979) was used to measure organizational commitment. The scale ranges from [1] strongly disagree to [7] strongly agree, indicating a high level of commitment. This instrument has been used in the accounting area by the authors Nouri and Parker (1998), Subramaniam et al. (2002), Chong et al. (2006), Parker and Kyj (2006), Chong and Johnson (2007), Nor Yahya et al. (2008), Ni et al. (2009), Sugioko (2010) and Wong-OnWing et al. (2010).

The managerial performance was measured using the nine-indicator scale by Mahoney et al. $(1963,1965)$. From this instrument, managers with budgetary responsibilities were asked to eval- 
uate their individual performance concerning eight dimensions of performance: planning, research, negotiation, coordination, supervision, selection, evaluation, representation and also evaluating their overall performance in activities budgetary. The instrument covers seven points, ranging from: [1] below-average performance to [7] above-average performance. This variable has also been used in the accounting area (Parker \& Kyj, 2006; Wong-On-Wing et al., 2010; Cheng, 2012; Jermias \& Yigit, 2013; Zonatto, 2014; Nguyen et al., 2016).

The data collection instrument was translated from English into Portuguese with the support of an English-speaking professional, and the most appropriate translations of the three constructs were considered for the study. We also compared the translations with research developed in Brazil in the accounting area and that used the instruments analyzed in this research, according to the procedure performed by Palomino (2013) and Zonatto (2014). After these procedures, intending to validate the questionnaire, a pre-test was conducted with a research professor in the area of managerial accounting, Doctor in Accounting Sciences and specialist in the analyzed subject, who carried out analyzes of the translation, adaptations made and the terminologies used, to verify if they agree with the budgetary researches in Brazil. A pre-test was also carried out with two doctoral students in Accounting and Administration Sciences and appreciated by two managers of large companies in Brazil. From this process, the reviewers detected questions that were not clear, which were corrected and passed again by an analysis of the professionals, being the instrument accepted and considered completed for the application.

A statistical pre-test was also carried out to identify problems with the research instrument. This pre-test had the participation of 37 (thirty-seven) managers with budgetary responsibilities, however, after this test, no other problems were identified. Subsequently, the research instrument was applied to the population considered, after tabulated, and analyzed, being validated through the alpha reliability test of cronbach. Data collection was done with the help of researchers from the Center for Studies and Research in Administration (CEPA), a body linked to the School of Administration of the Federal University of Rio Grande do Sul (EA/ UFRGS).

The questionnaire was applied by two interviewers, from telephone contact, at the beginning of September 2015, and ended in October 2015. In the telephone contact, the interviewers received guidance on the purpose of the research, the theoretical constructs used, and the research instrument, addressing each questioning to be carried out, to explain the meaning of each question. To ensure the reliability of the data collection, the research institute provided the list of called telephone numbers and call schedules, the name of the manager and the participating company, and the length of time to obtain the answers, which provided the possibility of checking the veracity of the information. Finally, the trajectory analysis was used to evaluate the hypotheses proposed.

The results of the relationships investigated in the present research are presented in the following topic.

\section{DESCRIPTION AND ANALYSIS OF RESULTS}

\subsection{Motivational Effects of Budgetary Participation}

The analysis of ways that address the motivational effects of budget participation, use as an independent variable the budgetary participation, mediating variable the organizational commitment, and dependent variable the managerial performance. Therefore, we seek to investigate the mediating effect of organizational commitment on the relationship between budget partici- 
pation and managerial performance. Table 1 presents the results of the motivational effects of budgetary participation in managerial performance, assessed through organizational commitment.

Table 1 - Summary of the initial model of evaluation of the motivational effects of the Budgetary Participation

\begin{tabular}{|c|c|c|c|c|c|}
\hline Dependent Variables & $\mathbf{R}$ & $\mathbf{R}^{\mathbf{2}}$ & Default Error & $\mathbf{F}$ & $\boldsymbol{P}$-value \\
\hline Organizational Commitment & 0,279 & 0,078 & 3,18538 & 12,499 & 0,001 \\
\hline Managerial Performance & 0,433 & 0,187 & 3,24942 & 16,960 & 0,000 \\
\hline
\end{tabular}

Source: Research data.

Changes in the workplace have increased competitiveness and brought about changes in working relationships and the way people are managed. One of these changes refers to organizational commitment, having the following bases: the acceptance of the organization's objectives; the perception of the feeling of loyalty and obligation towards the organization, intending to understand individuals and how to leverage their commitment to the organization (Falce et al., 2017). Therefore, from Table 1, it can be observed that organizational commitment is an important variable to be considered in the relationship between budgetary participation and managerial performance, as organizational commitment and managerial performance are significant at the level of $1 \%$. These results indicate that organizational commitment enhances the motivational effects of budgetary participation in managerial performance.

According to Mowday et al. (1982), the understanding of factors related to organizational commitment has implications not only for employees and organizations but also for society, which benefits from the organizational commitment of individuals in the organizations that act, presenting rates lower employee turnover in companies and higher productivity and quality of work. Thus, considering the positive effect of organizational commitment on the relationship between budget participation and managerial performance, the researchers in the managerial accounting area pay more attention to the variables that influence this commitment in organizations, to help top management increase the commitment of employees (Lau \& Tan, 2005). The relevance of the analysis of this variable in the relationship between budget participation and managerial performance is confirmed and the authors affirm that the intervening variables may explain the relationship between budgetary participation and managerial performance (Derfuss, 2016; Macinati et al., 2016; Dani et al., 2017).

To identify the direct relationships between the variables considered in the study, Table 2 shows the results of the concurrent model of analysis of the motivational effects of budgetary participation.

Table 2 - Coefficients of the regression of the concurrent model of analysis of the motivational effects of the Budgetary Participation

\begin{tabular}{|c|c|c|c|c|}
\hline Dependent Variables & Independent Variable & $\begin{array}{c}\text { Coefficient of } \\
\text { Path }\end{array}$ & T-value & P-value \\
\hline Organizational Commitment & Budgetary Participation & 0,279 & 7,084 & 0,000 \\
\hline \multirow{2}{*}{ Managerial Performance } & Budgetary Participation & 0,285 & 3,682 & 0,000 \\
\cline { 2 - 5 } & Organizational Commitment & 0,256 & 3,305 & 0,001 \\
\hline
\end{tabular}

Source: Research data.

According to the results in Table 2 , there is a positive relationship between budgetary participation and managerial performance, with a positive path coefficient of 0.285 and significant at the $1 \%$ level. This result reveals that budgetary participation has potential motivational effects on the managers with budgetary responsibilities, as it had a positive impact on their performance in 
the work. Similar results were found by Nouri and Parker (1998), Mia and Patiar (2002), Lau and Tan (2005), Chong et al. (2006), Agbejule and Saarikoski (2006), Chong and Johnson (2007), Nor Yahya et al. (2008), Sugioko (2010), Noor and Othman (2012) and Almasi et al. (2015). In this sense, the arguments of Hariyanti et al. (2015) are confirmed because they address that the involvement of managers in the budget process is a behavior that can have positive impacts on the performance of managers at work.

It has also been shown that there is a positive relationship between budgetary participation and organizational commitment, revealing a positive and significant path coefficient of 0.279 . From this finding, it can be confirmed that the budget participation leads to increasing levels of organizational commitment, through the involvement and influence of managers in the development of the budget of their units, which consequently compromises them more with the organization as a whole. This result presupposes that managers who participate in the budget processes have higher levels of commitment to the organization. These findings are consistent with previous research that also showed a positive relationship between budgetary participation and organizational commitment (Nouri \& Parker, 1998; Subramaniam \& Mia, 2001; Subramaniam et al., 2002; Chong et al., 2006; Nor Yahya et al., 2008; Ni et al., 2009; Sugioko, 2010; Wong-On-Wing et al., 2010; Noor \& Othman, 2012; Almasi et al., 2015).

Finally, the organizational commitment was positively related to the performance of the managers in the work, as it presented a positive and significant coefficient of 0.256 . Based on this result, it is noticed that managers with higher levels of organizational commitment also perform their work activities successfully, that is, they present positive managerial performance. The research developed by (Nouri \& Parker, 1998; Chong et al., 2006; Nor Yahya et al., 2008; Ni et al., 2009; WongOn-Wing et al., 2010; Noor \& Othman, 2012), corroborate with the findings of the present research, since the organizational commitment presented the association with the managerial performance in the work environment. For a better understanding of the results presented in Table 2, in Figure 2, we present the paths of the concurrent model of analysis of the motivational effects of budgetary participation.

Figure 2 - Coefficients of the concurrent model of analysis of the motivational effects of the Budgetary Participation

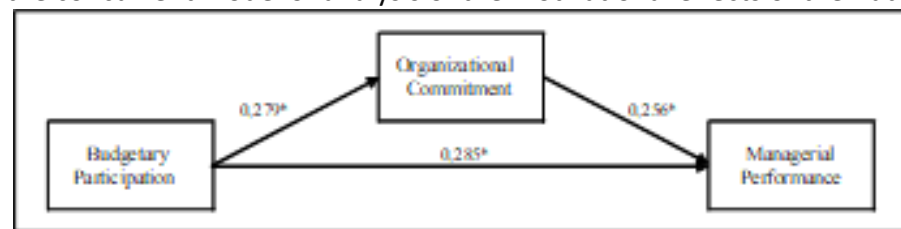

* The correlation is significant at the $1 \%$ level.

Source: Research data.

Considering the results found, this study confirmed the three proposed conditions for the sample considered, as the correlation between budgetary participation and managerial performance was evidenced in the study. Second, the budget participation was related to the organizational commitment and, finally, the organizational commitment was related to managerial performance. It is noteworthy that the aforementioned results suggest that budget participation affects managerial performance in budget activities, both directly and indirectly through the commitment of managers to the organization.

In this sense, managers committed to the organization make a greater effort to achieve the company's goals and have a more positive relationship within the organization (Serna et al., 2018). Also, greater organizational commitment better links managers with the organization, leading them 
to employ greater efforts on their behalf (Silva et al., 2018).

The management implications derived from the evidence show that in general, budget participation is a key management tool to deal with increasingly competitive and complex working environment circumstances as it has positive impacts on managers and organizations (Cheng, 2012). Therefore, through budget participation, managers can provide information relevant to the definition of budget goals and interact with this process, obtaining feedback from superiors intending to improve the budget process (Noor \& Othman, 2012), which affects the commitment of managers with the organization and their performance at work.

\subsection{Discussion of the results: Motivational effects of the Budgetary Participation on Managerial Performance}

As already discussed, several studies developed in the accounting area investigated the relationship between budget participation and managerial performance and found mixed results (Derfuss, 2016), which stimulated the development of this study through the motivational effects of the budgetary participation in this relation, taking into account the commitment of the managers with budgetary responsibilities with the organization. To do so, this research provided an examination of the link between budgetary participation and managerial performance, through organizational commitment.

The present study has several important implications for top management in Brazilian organizations with operations in the export sector, based on the verified results. Initially, the results suggest that budgetary participation has a positive effect on managerial performance in budget activities. This result reveals that the budget configuration in organizations should not be authoritarian, that is, from top to bottom, but from the bottom up, where top management must obtain feedback from managers of the most diverse levels intending to improve the budget process and subsequently the development of the budget of an organization (Nor Yahya et al., 2008).

This relationship also indicates that participation in budget activities provides better communication between superiors and their managers (Shields \& Shields, 1998; Francis-Gladney et al., 2004), which broadens relations between them (Mia \& Patiar, 2002) and improved managerial performance (Almasi et al., 2015) when their attitudes and motivations stemming from the incentive to participate in the budget processes are favorable in this context (Dani et al., 2017). Besides, budgets are useful tools that support the improvement of managers' and organization's performance through their ability to predict activities to be undertaken, manage resources, and implement effective control (Lidia, 2015). In this way, the results confirm the first hypothesis (H1) investigated in the research, indicating that there is a direct influence of the budgetary participation in managerial performance.

In second and third place, the findings show that when managers with budgetary responsibilities are allowed to become involved and influence the budget definition of their units (budgetary participation), they feel more committed to the organization and this commitment will lead to better management activities in the budget context. According to Macinati et al. (2016), contextual organizational resources, such as organizational practices (among which budget participation stands out), can support managers' behaviors, as in this research case the commitment to the organization. Thus, the organizational commitment leads to a better performance in the work, as the managers more committed to the organization will be more motivated and dedicated to the accomplishment of its activities. To strengthen these relationships in organizations, managers should be trained to improve their knowledge of the budget (Noor \& Othman, 2012). 
Thus, it can be confirmed in this research, the findings of Silva et al. (2016), because they found evidence that organizational commitment is composed of elements of attitudinal nature that includes beliefs, affections and intentions, as well as behavioral elements, which are the attitudes generated by the commitment, as the budget participation had positive effects on the organizational commitment and this with the managerial performance. Therefore, such characteristics of organizational commitment, addressed by Silva et al. (2016), are present in the managers with budget responsibilities researched in the study.

Given these results, companies need to ensure that mid-level managers continue to participate in budget processes and that higher-level managers seek a higher level of involvement and participation of these managers of the budget process, as these factors have positive effects on the performance of individuals at work. In this sense, superiors need to understand that the positive effects of budget participation on managerial performance occur both directly through involvement in this process and indirectly when managers' commitment to the organization increases in function of their active participation in budget processes (Nor Yahya et al., 2008).

In this context, it can be seen that organizational commitment can be considered one of the determinants of the performance of managers with budgetary responsibilities in the largest Brazilian companies with export operations. Evidence found in the literature supports this relationship (Nouri \& Parker, 1998; Chong et al., 2006; Nor Yahya et al., 2008; Ni et al., 2009; Wong-On-Wing et al., 2010; Noor \& Othman, 2012). The identification of the managers with the organization favors the accomplishment of their tasks, thus influencing the level of effort employed in such activities, that is, the managers' commitment to the organization favors their managerial performance in the budget activities (Zonatto, 2014). To do so, employees highly committed to the organization will be more willing to put a greater effort into carrying out their activities at work and achieve the objectives (Mowday et al., 1974; Ni et al., 2009). Managers with higher levels of budgetary participation tend to present higher levels of organizational commitment, given the greater involvement in the work and, consequently, positively impact managerial performance in the budget context (Nouri \& Parker, 1998; Chong et al., 2006; Wong-On-Wing et al., 2010; Noor \& Othman, 2012).

Likewise, the findings of previous studies have suggested that from budgetary participation it becomes possible to increase levels of organizational commitment and performance at work (Nouri \& Parker, 1998; Subramaniam \& Mia, 2001; Subramaniam et al., 2002; Chong et al., 2006; Nor Yahya et al., 2008; Ni et al., 2009; Sugioko, 2010; Wong-On-Wing et al., 2010; Noor \& Othman, 2012; Almasi et al., 2015). Therefore, the level of participation of the managers in the budget processes, impacts on the commitment with the organization (Subramaniam et al., 2002) and, the budgetary participation has direct and indirect effects on the performance, which allows enhancing the managerial performance ( $\mathrm{Ni}$ et al., 2009; Sugioko, 2010; Hariyanti et al., 2015). These results confirm the evidence that individuals participate in budgeting to improve their managerial performance (Hariyanti et al., 2015).

In this research, organizational commitment is related to the degree of identification of the individual with the organization (Mowday et al., 1979). In this way, when managers are willing to put more effort into the development of activities to help the organization, they speak enthusiastically about the company in which they work, accept work assignments, align personal and organizational values, take pride in the company in which they work, it inspires them to carry out the activities; they feel happy to work in the organization and they care about the destiny of the company. Thus, these managers tend to focus more on achieving better job performance, and these motivations are encouraged in individuals through participation in the budget processes. On the other hand, all of these factors, related to the tasks, activities to be carried out and work and organizational factors, 
can reduce the levels of commitment of managers with budgetary responsibilities and, in turn, their performance.

For this, the results found in this research also confirm the second and third hypotheses investigated in the research, suggesting the direct effect of the budgetary participation on the organizational commitment $(\mathbf{H 2})$ and the relation of this variable with the managerial performance in the budgetary activities (H3). Therefore, it is verified that the motivational element of the budget participation influences the managerial performance in the budget activities of the managers of the largest Brazilian companies with export operations, through the increase of the commitment of the managers with the organization.

\section{FINAL CONSIDERATIONS}

This research sought to broaden the literature discussion on the role of budget processes and their implications for organizational commitment and managerial performance in budget activities. The participation of managers in the budget processes contributed positively to a better managerial performance of the managers surveyed. From this result, it is pointed out that budget participation is a means for managers to be more involved in defining their budgets, to provide and receive information for budget review, to have the autonomy to express opinions and make suggestions on budgetary matters, have an influence on the final budget, contribute to the development of the budget, and also exchange and issue useful information on the forecasts, which consequently has positive effects for the execution of budget activities, such as tasks related to planning, negotiation, coordination, supervision, selection, evaluation, and representation.

This result suggests that organizations should encourage budgetary participation, as a positive effect on performance has been demonstrated. This finding is important, as the results of studies reviewed in the literature related to this relationship were mixed. Therefore, the present research indicates that behavioral aspects that relate to the budget process have significant implications for the results related to the work.

The results also revealed that the participation of the managers in the budgetary processes positively influences the commitment of the managers with the organization. Thus, from the organizational commitment construct, it was possible to identify the levels of involvement and influence of the managers with the definition of the budget, as well as, that the feeling of pride, of feeling part of the company, of being happy with the company that works and the concern with the destiny of the organization are factors that are leveraged through budget participation and that make the managers commit to the organization in which they work. From this result, it can be suggested that the organizational commitment can be promoted among the managers through the participative budget configuration. Thus, the impact on work-related outcomes is a function of organizational and individual variables, such as organizational commitment. Moreover, according to Subramaniam et al. (2002), as managers receive greater responsibilities and autonomy in budget processes, they become more willing and motivated to participate in budget definitions, which, in turn, elevates commitment to work and organization, as evidenced in this study.

It was verified that the managers' commitment to the organization positively influences their behavior and performance in budget activities. In this sense, managers who are more committed to the organization tend to use a higher level of effort to carry out their activities related to the budget, which will also influence their performance in these activities. This result suggests that to obtain a higher performance of the managers in the work, it is necessary to implement actions that stimulate their commitment to the organization and the active participation of the budget process, 
as these variables jointly favor the managerial performance. Thus, feeling committed to the organization influences individuals' behavior at work and has positive effects on managerial performance in budget activities.

Overall, the results also indicate that budget participation indirectly affects the manager's performance in budget activities, through the intermediary variable of organizational commitment. These results provide additional evidence on the effects of budget participation on managerial performance and the mediating role of organizational commitment in this relationship. Based on these findings, it is noted that organizational commitment enhances the relationship between budget participation and managerial performance, being a relevant variable to be considered in organizations that aim for the positive performance of managers in their work activities. Her et al. (2018) denote that managers need to be given greater opportunity and ability to engage in a wide range of budget activities to help them achieve their goals, which consequently affects their commitment to the organization and their work performance.

Thus, based on the study carried out from Brazilian companies with export operations, it can be concluded that the process of budgetary participation has positive and significant effects on managerial performance. Also, organizational commitment has played a significant role in the relationship between budget participation and work performance, which indicates that organizations should encourage the participation of managers at all levels in budget activities, since the benefit of this participation for the individual and organization. Therefore, it should be noted that the existence of such confirmed influences in the Brazilian scenario should be observed for the identification of factors that may favor or even diminish the performance of the manager in activities directed to the budget.

The results evidenced in this study contribute to the understanding of the relationships between budget participation, organizational commitment, and managerial performance in budget activities, which can help organizations in understanding the factors that can be improved in the organization so that employees feel committed to the company in which they operate and consequently present better budgetary participation and performance at work. The study also contributes to the budget literature, since it helps to reconcile the results evidenced by previous research in the area, and thus to improve the understanding of the relationships among the factors that stimulate the managerial performance in budgetary activities, in the context of budgetary participation and commitment to the organization.

For this, the study contributes to the literature, because according to the results, the benefits of budget participation can only be achieved when managers have a better understanding of their tasks, perceive the objectives for which they are responsible, and are committed to the objectives organizations. It also contributes to the literature, considering the incorporation of a mediating variable and the result of the managers' participation in the budget processes. Thus, this study sheds light on the motivational effects of budgetary participation and the conditions under which budget participation improves organizational commitment and performance at work.

However, the results of this study are subject to some limitations. Only managers with budgetary responsibilities of large companies with export operations were analyzed, so the results cannot be generalized to organizations that differ from this sector. Another limitation is the research approach, as it used self-reported measures to measure the proposed relationships. Despite these limitations, it can be seen that budget participation can have important positive consequences for organizations, as it can facilitate the performance of managers at work. This participation can also increase levels of organizational commitment, which will lead to positive results at work, such as greater managerial performance. 
As this research analyzed the organizational commitment as an intervening variable in the relationship between budgetary participation and managerial performance, it is suggested for future research the investigation of other mediating variables in this relation, such as job satisfaction, motivation for budget participation, role ambiguity, among others and organizational factors such as corporate culture, as other variables can play an important role in the relationship between participation and performance. Besides, it is recommended for future research to analyze the effects of additional variables from the area of psychology, organizational behavior, and behavioral area of accounting.

\section{REFERENCES}

AGBEJULE, A. \& SAARIKOSKI, L. (2006). The effect of cost management knowledge on the relationship between budgetary participation and managerial performance. The British Accounting Review, 38(4), 427-440.

ALMASI, H., PALIZDAR, M. R., \& PARSIAN, H. A. (2015). Budgetary participation and managerial performance: The impact of information and environmental volatility. Management Science Letters, 5, 843-854.

CHENG, M. T. (2012). The joint effect of budgetary participation and broadscope management accounting systems on management performance. Asian Review of Accounting, 20(3), 184197.

CHONG, V. K., EGGLETON, I. R. C., \& LEONG, M. K. C. (2006). The Multiple Roles of Participative Budgeting on Job Performance. Advances in Accounting, 22, 67-95.

CHONG, V. K., \& JOHNSON, D. (2007). Testing a Model of the Antecedents and Consequences of Budgetary Participation on Job Performance. Accounting and Business Research, 37(1), 0319.

COVALESKI, M., EVANS III, J. H., LUFT, J., \& SHIELDS, M. D. (2007). Budgeting research: three theoretical perspectives and criteria for selective integration. In. Chapman, C. S., Hopwood, A. G., \& Shields, M. D. Handbook of Management Accounting Research, 2(Cap. 6), 587-624.

DAKHLI, A. (2010). Budgetary participation in a non-western country. Journal of Business in Developing Nations, 12, 1-31.

DANI, A. C., ZONATTO, V. C. DA S., \& DIEHL, C. A. (2017). Budget Participation and Managerial Performance: A Meta-Analysis of Relationships Found in Research Developed in the Behavioral Behavior of Accounting. Advances in Scientific and Applied Accounting, 10(1), 54-72.

DERFUSS, K. (2016). Reconsidering the participative budgeting-performance relation: A metaanalysis regarding the impact of the level of analysis, sample selection, measurement, and industry influences. The British Accounting Review, 48(1), 17-37.

ELIYANA, A., \& MA'ARIF, S. (2019). Job satisfaction and organizational commitment effect in the transformational leadership towards employee performance. European Research on Management and Business Economics, 25(3), 144-150.

ETEMADI, H., DILAMI, Z. D., BAZAZ, M. S., \& PARAMESWARAN, R. (2009). Culture, management accounting and managerial performance: Focus Iran. Advances in Accounting, Incorporating 
Advances in International Accounting, 25(2), 216-225.

FALCE, J. L. L., PAIVA, K. C. M. DE., MUYLDER, C. F. DE., \& MORAIS, M. M. DOS S. (2017). Organizational Commitment: Longitudinal Study in a Public Higher Education Organization. Revista de Administração Mackenzie, 18(6), 124-148.

FRANCIS-GLADNEY, L., LITTLE, H. T., MAGNER, N. R., \& WELKER, R. B. (2004). Does OrganizationMandated Budgetary Involvement Enhance Managers'budgetary Communication with their Supervisor?. Advances in Management Accounting, 13(1), 167-182.

GAGNÉ, M., \& DECl, E. (2005). Self-determination theory and work motivation. Journal of Organizational Behavior, 26(4), 331-362.

HARIYANTI, W., PURNAMASARI, P., \& LESTIRA O, M. (2015). Pluriform motivation as antecedent and its relationships to budgeting participation and managerial performance (Empirical Study on Manufacturing Companies listed on Indonesian Stock Exchange). Procedia Social and Behavioral Sciences, 211, 836-843.

HER, Y. W., SHIN, H., \& PAE, S. (2018). A multigroup SEM analysis of moderating role of task uncertainty on budgetary participation-performance relationship: Evidence from Korea. Asia Pacific Management Review, 24(2), 140-153.

JERMIAS, J., \& YIGIT, F. (2013). Budgetary participation in Turkey: The effects of information asymmetry, goal commitment, and role ambiguity on job satisfaction and performance. Journal of International Accounting Research, 12(1), 29-54.

KETCHAND, A. A., \& STRAWSER, J. R. (2001). Multiple dimensions of organizational commitment: Implications for future accounting research. Behavioral Research in Accounting, 13(1), 221251.

LAU, C. M., \& TAN, S. L. (2005). The importance of procedural fairness in budgeting. Advances in Accounting, 21(1), 333-356.

Leite, N. R. P., RODRigues, A. C. DE A., \& AlbuQUerque, L. G. DE. (2014). Organizational commitment and job satisfaction: what are the potential relationships?. Brazilian Administration Review, 11(4), 476-495.

LIDIA, T. G. (2015). An analysis of the existence of a link between budgets and performance in economic entities. Procedia Economics and Finance, 32, 1794-1803.

MACINATI, M. S., BOZZI, S., \& RIZZO, M. G. (2016). Budgetary participation and performance: The mediating effects of medical managers' job engagement and self-efficacy. Health Policy, 120(9), 1017-1028.

MAHONEY, T. A., JERDEE, T. H., \& CARROLL, S. J. (1963). Development of Managerial Performance: A Research Approach. Cincinnati, $\mathrm{OH}$ : South-Western Publishing.

MAHONEY, T. A., JERDEE, T. H., \& CARROLL, S. J. (1965). The job(s) of management. Industrial Relations, 4(2), 97-110.

MIA, L., \& PATIAR, A. (2002). The interactive effect of superior-subordinate relationship and budget participation on managerial performance in the hotel industry: an exploratory study. Journal 
of Hospitality \& Tourism Research, 26(3), 235-257.

MILANI, K. (1975). The relationship of participation in budget-setting to industrial supervisor performance and attitudes: a field study. The Accounting Review, 50(2), 274-284.

MOWDAY, R., PORTER, L., \& DUBIN, R. (1974). Unit performance, situational factors and employee attitudes in spatially separated work units. Organizational Behavior and Human Performance, 11(2), 231-248.

MOWDAY, R., PORTER, L., \& STEERS, R. (1982). Organizational Linkages. New York: Academic Press.

MOWDAY, R. T., STEERS, R. M., \& PORTER, L. W. (1979). The measurement of organizational commitment. Journal of Vocational Behavior, 14(2), 224-247.

NGUYEN, T. T., MIA, L., WINATA, L., \& CHONG, V. K. (2016). Effect of transformational-leadership style and management control system on managerial performance. Journal of Business Research, 70, 202-213.

NI, F. Y., SU, C. C., CHUNG, S. H., \& CHENG, K. C. (2009). Budgetary participation's effect on managerial outcomes: Mediating roles of self-efficacy and attitudes toward budgetary decision makers. NTU Management, 19(2), 321-347.

NOOR, I. H. B. M., \& OTHMAN, R. (2012). Budgetary participation: How it affects performance and commitment. Accountancy Business and the Public Interest, 1, 53-73.

NOR YAHYA, M., NIK AHMAD, N. N., \& FATIMA, A. H. (2008). Budgetary participation and performance: some Malaysian evidence. International Journal of Public Sector Management, 21(6), 658-673.

NOURI, H., \& PARKER, R. J. (1998). The relationship between budget participation and job performance: The roles of budget adequacy and organizational commitment. Accounting, Organizations and Society, 23(5/6), 467-483.

ORTIZ, D. A. C., SALGADO, P. M., \& CÁZARES, F. L. (2018). Satisfacción laboral y compromiso organizacional: prueba de equivalencia de medición entre México y Estados Unidos. Contaduría y Administración, 63(2), 1-18.

OTLEY, D. T. (1978). Budget use and managerial performance. Journal of Accounting Research, 16(1), 122-149.

PALOMINO, M. N. (2013). Conflict, role ambiguity and satisfaction at work: perceptions of Brazilian controllers. $136 \mathrm{f}$. Dissertation (Master in Accounting) - Graduate Program of the University of São Paulo, São Paulo.

PARKER, R. J., \& KYJ, L. (2006). Vertical information sharing in the budgeting process. Accounting, Organizations and Society, 31(1), 27-45.

PORTER, L. W., STEERS, R. W., MOWDAY, R. T., \& BOULIAN, P. V. (1974). Organizational commitment, job satisfaction, and turnover among psychiatric technicians. Journal of Applied Psychology, 59(5), 603-609.

RENGEL, R., MONTEIRO, J. J., LUNKES, R. J., LAVARDA, C. E. F., \& SCHNORRENBERGER, D. (2020). 
Efeito das Características dos Gestores na Participação Orçamentária mediado pela Percepção de Justiça Processual. Contabilidade, Gestão e Governança, 23(2), 256-275.

RONEN, J., \& LIVINGSTONE, J. (1975). An expectancy theory approach to the motivational impact of budgets. The Accounting Review, 50(4), 671-685.

SERNA, M. D. C. M., MARTÍNEZ, J. E. V., \& DOMENEC, V. E. (2018). The influence of organizational commitment and learning orientation on innovation in SMEs. Contaduría y Administración, 63(3), 1-19.

SHIELDS, J. F., \& SHIELDS, M. D. (1998). Antecedents of participative budgeting. Accounting, Organizations and Society, 23(1), 49-76.

SILVA, L. P. DA., CASTRO, M. A. R., SANTOS, M. G. DOS., \& LIMA NETO, P. J. DE. (2018). Comprometimento no trabalho e sua relação com a cultura organizacional mediada pela satisfação. Revista Brasileira de Gestão de Negócios, 20(3), 401-420.

SILVA, C. C., LEITE, N. R. P., \& RODRIGUES, L. C. (2016). Gestão estratégica de pessoas e comprometimento organizacional em organizações hospitalares. Revista de Administração da Universidade Federal de Santa Maria, 9(2), 192-209.

SOARES, M. L., TEIXEIRA, O. R. D. P., \& PELISSARI, A. S. (2011). Comportamento organizacional: uma aplicação da tipologia de Miles e Snow no setor hoteleiro de Florianóplis, SC. Revista de Administração da Universidade Federal de Santa Maria, 4(2), 251-267.

SUBRAMANIAM, N., MCMANUS, L., \& MIA, L. (2002). Enhancing hotel managers' organisational commitment: an investigation of the impact of structure, need for achievement and participative budgeting. International Journal of Hospitality Management, 21(4), 303-320.

SUBRAMANIAM, N., \& MIA, L. (2001). The relation between decentralised structure, budgetary participation and organisational commitment: the moderating role of managers' value orientation towards innovation. Accounting, Auditing \& Accountability Journal, 14(1), 12-29.

SUGIOKO, S. (2010). The Impact of budget participation on job performance of university executives: A study of APTIK-Member Universities in Indonesia. Kasetsart Journal, 31, 271-279.

VENKATESH, R., \& BLASKOVICH, J. (2012). The mediating effect of psychological capital on the budget participation-job performance relationship. Journal of Management Accounting Research, 24(1), 159-175.

WONG-ON-WING, B., GUO, L., \& LUI, G. (2010). Intrinsic and Extrinsic Motivation and Participation in Budgeting: Antecedents and Consequences. Behavioral Research in Accounting, 22(2), 133-153.

ZONATTO, V. C. DA S. (2014). Influence of cognitive social factors of capacity, will, and opportunity on managerial performance in the budget activities of the largest exporting companies in Brazil. $411 \mathrm{f}$. Thesis (Doctorate in Accounting and Administration) - Post-Graduate Program in Accounting Sciences, Regional University of Blumenau, Blumenau. 


\section{AUTHORS}

\section{Andréia Acássia Guidini}

Master of Science in Accounting from Regional University of Blumenau (FURB), and Teacher at University of the Contestado (UnC). Mafra, Santa Catarina (SC), Brazil

E-mail: guidiniandreia@hotmail.com

ORCID: https://orcid.org/0000-0001-7919-620X

\section{Vinícius Costa da Silva Zonatto}

$\mathrm{PhD}$ in Accounting and Administration from Regional University of Blumenau (FURB) and Teacher at Federal University of Santa Maria (UFSM). Santa Maria, Rio Grande do Sul (RS), Brazil

E-mail: viniciuszonatto@gmail.com

ORCID: https://orcid.org/0000-0003-0823-6774

\section{Larissa Degenhart}

$\mathrm{PhD}$ in Accounting and Administration from Regional University of Blumenau (FURB) and Teacher at Federal University of Santa Maria (UFSM). Santa Maria, Rio Grande do Sul (RS), Brazil

E-mail: lari_ipo@hotmail.com

ORCID: https://orcid.org/0000-0003-0651-8540

\section{Contribution of authors.}

\begin{tabular}{|l|c|c|c|}
\hline \multicolumn{1}{|c|}{ Contribution } & [Author 1] & [Author 2] & [Author 3] \\
\hline 1. Definition of research problem & $\mathrm{V}$ & $\mathrm{V}$ & $\mathrm{V}$ \\
\hline $\begin{array}{l}\text { 2. Development of hypotheses or research questions } \\
\text { (empirical studies) }\end{array}$ & $\mathrm{V}$ & & \\
\hline $\begin{array}{l}\text { 3. Development of theoretical propositions } \\
\text { (theoretical work) }\end{array}$ & $\mathrm{V}$ & $\mathrm{V}$ & $\mathrm{V}$ \\
\hline 4. Theoretical foundation/Literature review & $\mathrm{V}$ & $\mathrm{V}$ & \\
\hline 5. Definition of methodological procedures & $\mathrm{V}$ & & \\
\hline 6. Data collection & $\mathrm{V}$ & $\mathrm{V}$ & $\mathrm{V}$ \\
\hline 7. Statistical analysis & $\mathrm{V}$ & $\mathrm{V}$ & $\mathrm{V}$ \\
\hline 8. Analysis and interpretation of data & $\mathrm{V}$ & $\mathrm{V}$ & $\mathrm{V}$ \\
\hline 9. Critical revision of the manuscript & $\mathrm{V}$ & $\mathrm{V}$ & \\
\hline 10. Manuscript writing & & & \\
\hline 11. Other (please specify) & & \\
\hline
\end{tabular}

